\title{
Performance of Ultrasound for Identifying Morphological Characteristics and Thickness of Cutaneous Basal Cell Carcinoma: A Systematic Review
}

\author{
Alexandra Laverde-Saad ${ }^{\mathrm{a}} \quad$ Alexe Simard $^{\mathrm{b}}$ David Nassim $^{\mathrm{b}} \quad$ Abdulhadi Jfri $^{\mathrm{a}}$ \\ Ali Alajmi $^{\mathrm{a}}$ Elizabeth O'Brien ${ }^{\mathrm{a}}$ Ximena Wortsman ${ }^{\mathrm{c}, \mathrm{d}, \mathrm{e}}$ \\ aDivision of Dermatology, McGill University Health Centre, Montreal General Hospital, Montreal, QC, Canada; \\ ${ }^{b}$ Faculty of Medicine, McGill University, Montreal, QC, Canada; Institute for Diagnostic Imaging and Research \\ of the Skin and Soft Tissues, Santiago, Chile; ${ }^{d}$ Department of Dermatology, Faculty of Medicine, Universidad de \\ Chile, Santiago, Chile; e'Department of Dermatology, School of Medicine, Pontificia Universidad Católica de Chile, \\ Santiago, Chile
}

\section{Keywords}

Ultrasound · Basal cell carcinoma $\cdot$ High-frequency ultrasound $\cdot$ Imaging $\cdot$ Non-melanoma skin cancer

\begin{abstract}
Advances in ultrasound technology and non-surgical treatments of basal cell carcinomas (BCCs) have raised the need to study the performance of high-frequency ultrasound (HFUS) in BCCs. We aimed to assess the performance of HFUS in the evaluation of BCCs to formulate recommendations for its uses and conducted a systematic review of the literature to do so. A search of Central, Medline, Embase, CINHAL, and Web of Science was performed using key/MESH terms "ultrasonography" and "basal cell carcinoma" (January 2005-December 2020). We included primary studies reporting biopsy-confirmed BCCs for which the target intervention was ultrasound assessment at $15 \mathrm{MHz}$ or higher frequency. Thirty articles were included, studying a total of 1,203 biopsy-confirmed BCCs. HFUS provides accurate depth measurements, especially for BCCs $>1 \mathrm{~mm}$. The definition of lateral margins in vivo needs further studies; however, ex vivo margin assessment seems convincing. There is a diagnostic role for HFUS in identifying higher recurrence risk BCC subtypes,
\end{abstract}

which can help in risk stratification. Performance of HFUS is significant in BCC management. Pre-surgical scans may support case selection for Mohs. HFUS can improve safety when used to plan brachytherapy treatments, help with case selection and adjunct treatment choice pre-photodynamic therapy. Finally, HFUS can help follow lesions after intervention, particularly non-surgical management, and support the decision to observe or re-intervene. HFUS can enhance clinical practice by providing useful information that cannot be deducted from the clinical examination. It would be recommended to evaluate the extent, mainly depth, and detect the aggressiveness of the BCCs.

(c) 2022 S. Karger AG, Basel

\section{Introduction}

Basal cell carcinomas (BCCs) are the most common type of cancer in the Caucasian population, with the lifetime risk of developing a BCC estimated to be equal to or greater than 20\% in the United States [1] and an incidence rate that continues to rise in North America, Asia [2], Europe $[3,4]$, and Australia $[5,6]$. Most BCCs occur on the head and neck [7] and while they rarely metastasize $(<0.1 \%)$ karger@karger.com

(c) 2022 S. Karger AG, Basel

www.karger.com/drm

Karger\%
Correspondence to:

Alexandra Laverde-Saad, alexandra.laverde-saad@mail.mcgill.ca 
[8], they can be locally invasive and cause great morbidity [7]. Biopsy remains the gold standard for diagnosis [9]; however, with the development and increasing use of topical, intralesional, photodynamic, laser, and radiation treatments as well as most recently hedgehog inhibitors $[10,11]$, a non-invasive diagnostic approach can be favored. Imaging techniques such as reflectance confocal microscopy [12], optical coherence tomography [13], and ultrasound have been studied to assess BCCs. Ultrasound's accessibility, non-invasive nature, safety, and ability to provide information in real-time makes it an invaluable tool in the assessment of dermatological lesions, including BCCs. High-frequency ultrasound (HFUS; e.g., $\geq 15 \mathrm{MHz}$ ) has high definition and penetration that generates welldemarcated images, and for this reason, it is considered a first-line imaging technique for the assessment of nonmelanoma skin cancers $[14,15]$. Basal cell carcinomas appear on ultrasound as a hypoechoic dermal or subdermal structure of variable shape that often contains tumoral hyperechoic spots. The number of these spots within one lesion has been used to discriminate high-risk versus lowrisk recurrence of BCC subtypes. Doppler assessment of BCCs usually shows low to moderate vascularity [16].

Significant technological advances in recent years in HFUS quality have allowed its applications to expand. Its role goes far beyond diagnostics, as it can help in the lesion characterization and ultimately contribute to surgical planning and monitoring of treatment response. Our systematic review aims to evaluate the performance of HFUS in diagnostic and non-diagnostic capacities for the assessment of BCCs to formulate recommendations for the applications of sonography for BCCs.

\section{Materials and Methods}

\section{Search Strategy}

A systematic search of Central, Medline, Embase, CINHAL, and Web of Science was performed using key/MESH terms "ultrasonography" and "basal cell carcinoma". References between January 2005 and December 2020 were considered. Primary studies in either English, French, or Spanish with a minimum of 7 histopathologically confirmed BCCs using ultrasound to assess these lesions were included. The initial search yielded 438 references, of which 90 duplicates were removed. The remaining studies were screened by title and abstract for relevance, and 141 articles were assessed in full by three independent evaluators. In total, 30 articles were included (see Fig. 1: PRISMA flow diagram).

\section{Inclusion and Exclusion Criteria}

We included primary studies reporting biopsy-confirmed BCCs for which the target intervention was ultrasound assessment at $15 \mathrm{MHz}$ or higher frequency. Studies reporting data on seven or

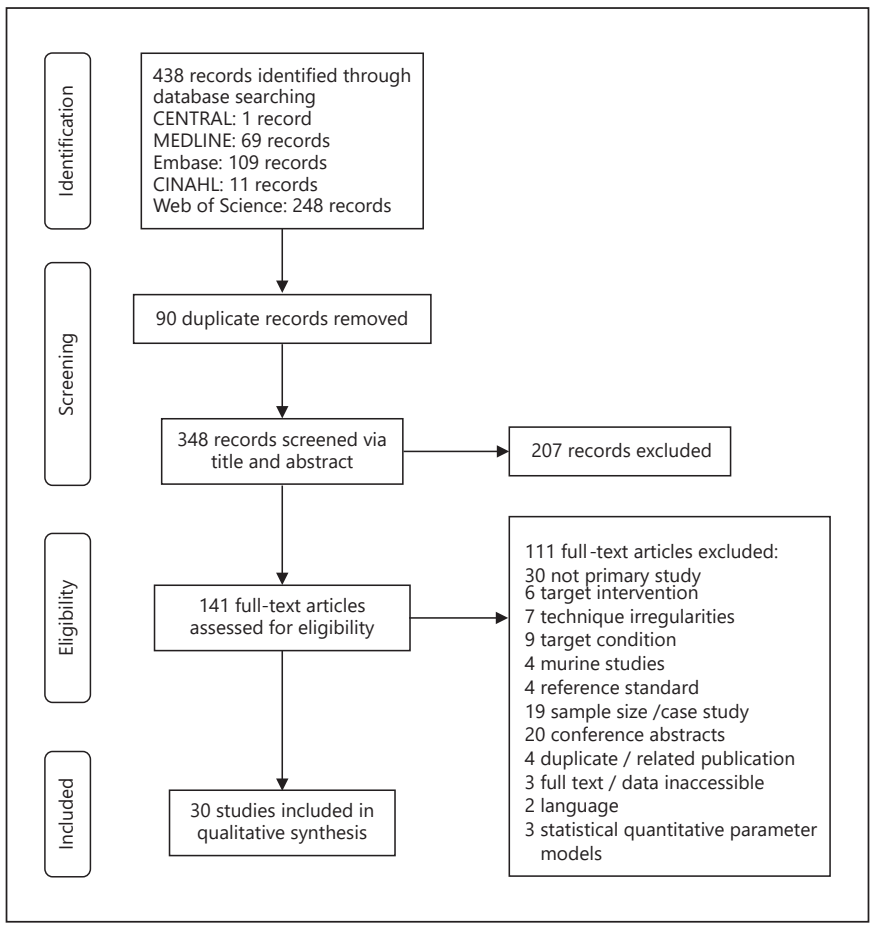

Fig. 1. PRISMA flow diagram of the systematic review of literature conducted.

more BCCs were considered. Murine studies and conference abstracts were excluded. Studies discussing other NMSC along with BCCs were considered.

\section{Quality Assessment}

We used the Quality Assessment of Diagnostic Accuracy Studies (QUADAS) checklist to evaluate the studies' quality [17]. This tool was created to be used in systematic reviews of diagnostic accuracy studies. Articles received a quality score based on the 14item checklist (eTable 1; see online suppl. material at www.karger. com/doi/10.1159/000520751). The Oxford Centre for EvidenceBased Medicine levels of evidence were established for each study and grade of recommendations were subsequently derived from these levels. This process was done by two independent authors (A.L.-S., A.S.) [18].

\section{Data Extraction}

Three independent authors (A.L.-S., A.S., D.N. - one dermatology resident and two medical students) extracted the data from the 30 studies included. Demographic, lesion characteristics, and general information pertaining to methodology were collected. Each study was categorized according to the uses they made of HFUS: (i) general lesion characteristics (size, depth, margins, invasion), (ii) diagnostic (primary diagnosis of BCC, subtype identification, subclinical and/or contiguous lesion identification), or (iii) management (surgical planning, non-surgical planning, monitoring). Studies may have been attributed more than one main objective. 
Table 1. General characteristics of studies included in this systematic review

\begin{tabular}{|c|c|c|c|c|c|c|c|}
\hline Study, country & Design & $\begin{array}{l}\text { QUADAS } \\
\text { score }\end{array}$ & $\begin{array}{l}\text { HFUS } \\
\text { maximum } \\
\text { frequency** }^{* *}\end{array}$ & Population & BCC characteristics & $\begin{array}{l}\text { Primary, post- } \\
\text { treatment or } \\
\text { recurrence }\end{array}$ & $\begin{array}{l}\text { Location of } \\
\text { lesions }\end{array}$ \\
\hline Bens 2015, France & Retrospective case series & 10 & $\begin{array}{l}20 \mathrm{MHz} \\
\text { In vivo }\end{array}$ & $\begin{array}{l}66 \text { patients } \\
\text { Mean age } 73 \text { (48-89) }\end{array}$ & $\begin{array}{l}33 \text { BCCs: } \\
8 \text { infiltrative } \\
25 \text { nodular }\end{array}$ & Primary & Face \\
\hline Bobadilla 2008, Chile & Cross-sectional study & 13 & $\begin{array}{l}15 \mathrm{MHz} \\
\text { In vivo }\end{array}$ & $\begin{array}{l}25 \text { patients } \\
15 \mathrm{M}, 10 \mathrm{~F} \\
\text { Mean age } 69.5(48-91)\end{array}$ & $\begin{array}{l}29 \text { BCCs: } \\
27 \text { nodular } \\
1 \text { morpheiform } \\
1 \text { adenoid }\end{array}$ & Primary & Face \\
\hline Crisan 2013, Romania & Prospective case series & 11 & $\begin{array}{l}20 \mathrm{MHz} \\
\text { In vivo }\end{array}$ & $\begin{array}{l}46 \text { patients } \\
20 \mathrm{M} \text {, mean age } 51.5 \\
26 \mathrm{~F} \text {, mean age } 42.3\end{array}$ & 18 nodular BCCs & Primary & $\begin{array}{l}\text { Face, trunk, } \\
\text { limbs }\end{array}$ \\
\hline Desai 2007, USA & Prospective case series & 8 & $\begin{array}{l}20 \mathrm{MHz} \\
\text { In vivo }\end{array}$ & NR & $\begin{array}{l}50 \text { BCCs: } \\
18 \text { superficial } \\
30 \text { nodular } \\
1 \text { morpheiform } \\
1 \text { infiltrative }\end{array}$ & Primary & NR \\
\hline Goyal 2017, USA - A* & Retrospective case series & 10 & $\begin{array}{l}18 \mathrm{MHz} \\
\text { In vivo }\end{array}$ & $\begin{array}{l}18 \text { patients } \\
9 \mathrm{M}, 9 \mathrm{~F} \\
\text { Mean age } 70(54-85)\end{array}$ & $17 \mathrm{BCCs}$ & Primary & $\begin{array}{l}\text { Face, ear, } \\
\text { scalp, } \\
\text { eyebrow, } \\
\text { limbs }\end{array}$ \\
\hline $\begin{array}{l}\text { Hernández-lbáñez } \\
\text { 2017, Spain }\end{array}$ & Retrospective case series & 12 & $\begin{array}{l}20 \mathrm{MHz} \\
\text { In vivo }\end{array}$ & $\begin{array}{l}\text { Nb of patients NR } \\
59 \% M, 41 \% \mathrm{~F} \\
\text { Mean age } 68\end{array}$ & $\begin{array}{l}156 \text { BCCs: } \\
45 \text { superficial } \\
43 \text { nodular } \\
48 \text { infiltrative } \\
7 \text { mixed superficial + } \\
\text { nodular } \\
5 \text { superficial + } \\
\text { infiltrative } \\
6 \text { nodular + } \\
\text { infiltrative } \\
2 \text { non-specific }\end{array}$ & Primary & $\begin{array}{l}\text { Head, neck, } \\
\text { trunk, arms }\end{array}$ \\
\hline
\end{tabular}


Table 1 (continued)

\begin{tabular}{|c|c|c|c|c|c|c|c|}
\hline Study, country & Design & $\begin{array}{l}\text { QUADAS } \\
\text { score }\end{array}$ & $\begin{array}{l}\text { HFUS } \\
\text { maximum } \\
\text { frequency** }\end{array}$ & Population & BCC characteristics & $\begin{array}{l}\text { Primary, post- } \\
\text { treatment or } \\
\text { recurrence }\end{array}$ & $\begin{array}{l}\text { Location of } \\
\text { lesions }\end{array}$ \\
\hline Hinz 2012, Germany & Prospective case series & 12 & $\begin{array}{l}20 \mathrm{MHz} \\
\text { In vivo }\end{array}$ & $\begin{array}{l}10 \text { patients } \\
9 \mathrm{M}, 1 \mathrm{~F} \\
\text { Mean age } 73.8(62-80)\end{array}$ & $\begin{array}{l}10 \text { BCCs: } \\
6 \text { superficial } \\
3 \text { solid } \\
1 \text { fibroepithelioma } \\
\text { of Pinkus }\end{array}$ & Primary & $\begin{array}{l}\text { Trunk, head, } \\
\text { limbs }\end{array}$ \\
\hline $\begin{array}{l}\text { Jambusaria-Pahlajani } \\
\text { 2009, USA* }\end{array}$ & Cross-sectional study & 12 & $\begin{array}{l}40 \mathrm{MHz} \\
\text { In vivo }\end{array}$ & $\begin{array}{l}98 \text { patients } \\
72 \mathrm{M}, 26 \mathrm{~F} \\
\text { Mean age } 63(18-95)\end{array}$ & $77 \mathrm{BCCs}$ & $\begin{array}{l}\text { Primary and } \\
\text { recurrent }\end{array}$ & Head, neck \\
\hline Jovanovic 2005, Serbia* & Prospective case series & 11 & $\begin{array}{l}20 \mathrm{MHz} \\
\text { In vivo }\end{array}$ & NR & $12 \mathrm{BCCs}$ & NR & NR \\
\hline $\begin{array}{l}\text { Khlebnikova 2018, } \\
\text { Russia }\end{array}$ & Prospective case control & 12 & $\begin{array}{l}75 \mathrm{MHz} \\
\text { In vivo }\end{array}$ & $\begin{array}{l}47 \text { patients, } \\
16 \mathrm{M}, 31 \mathrm{~F} \\
\text { Mean age } 64.8(56-73)\end{array}$ & $\begin{array}{l}60 \text { BCCs: } \\
35 \text { superficial } \\
22 \text { nodular } \\
3 \text { morpheiform }\end{array}$ & Primary & NR \\
\hline $\begin{array}{l}\text { Khlebnikova 2020, } \\
\text { Russia }\end{array}$ & Prospective case series & 14 & $\begin{array}{l}75 \mathrm{MHz} \\
\text { In vivo }\end{array}$ & $\begin{array}{l}19 \text { patients } \\
10 \mathrm{M}, 9 \mathrm{~F} \\
\text { Mean age } 65.3(48-82)\end{array}$ & $27 \mathrm{BCCs}$ & Primary & NR \\
\hline $\begin{array}{l}\text { Lippert 2013, Czech } \\
\text { Republic }\end{array}$ & Prospective case series & 10 & $\begin{array}{l}25 \mathrm{MHz} \\
\text { In vivo }\end{array}$ & $\begin{array}{l}56 \text { patients } \\
32 \mathrm{M}, 24 \mathrm{~F} \\
\text { Mean age } 61.9\end{array}$ & 56 nodular BCCs & NR & $\begin{array}{l}\text { Head, face, } \\
\text { neck, other }\end{array}$ \\
\hline Marmur 2010, USA & Prospective case series & 12 & $\begin{array}{l}20 \mathrm{MHz} \\
\text { In vivo }\end{array}$ & 20 patients & $\begin{array}{l}9 \text { BCCs: } \\
2 \text { nodular } \\
6 \text { superficial } \\
1 \text { atypical }\end{array}$ & NR & $\begin{array}{l}\text { Head and } \\
\text { neck, face, } \\
\text { limbs, trunk }\end{array}$ \\
\hline $\begin{array}{l}\text { Mogensen 2009, } \\
\text { Denmark* }\end{array}$ & Prospective case series & 12 & $\begin{array}{l}20 \mathrm{MHz} \\
\text { In vivo }\end{array}$ & $\begin{array}{l}93 \text { patients } \\
44 \mathrm{M}, 49 \mathrm{~F} \\
\text { Mean age } 70.6(37-90)\end{array}$ & $23 \mathrm{BCCs}$ & Primary & Face, other \\
\hline $\begin{array}{l}\text { Nassiri-Kashani 2013, } \\
\text { Iran }\end{array}$ & Prospective case series & 13 & $\begin{array}{l}50 \mathrm{MHz} \\
\text { In vivo }\end{array}$ & $\begin{array}{l}36 \text { patients } \\
29 \mathrm{M}, 7 \mathrm{~F} \\
\text { Mean age } 63.85(42-79)\end{array}$ & $56 \mathrm{BCCs}$ & Primary & Face, other \\
\hline Pasquali 2016, Spain* & Prospective case series & 12 & $\begin{array}{l}22 \mathrm{MHz} \\
\text { In vivo and } \\
\text { ex vivo }\end{array}$ & $\begin{array}{l}89 \text { patients } \\
52 \mathrm{M}, 37 \mathrm{~F} \\
\text { Mean age } 74.37\end{array}$ & $\begin{array}{l}79 \text { BCCs: } \\
56 \text { nodular } \\
15 \text { superficial } \\
8 \text { mixed }\end{array}$ & Primary & NR \\
\hline $\begin{array}{l}\text { Raszewska-Famielec } \\
\text { 2020, Poland }\end{array}$ & Prospective case series & 11 & $\begin{array}{l}20 \mathrm{MHz} \\
\text { In vivo }\end{array}$ & $\begin{array}{l}70 \text { patients } \\
27 \mathrm{M}, 43 \mathrm{~F} \\
\text { Mean age } 69.04(33-88)\end{array}$ & $\begin{array}{l}70 \text { BCCs: } \\
40 \text { nodular } \\
18 \text { superficial } \\
3 \text { micronodular } \\
3 \text { morpheiform } \\
6 \text { mixed }\end{array}$ & NR & NR \\
\hline $\begin{array}{l}\text { Smucler 2012, Czech } \\
\text { Republic }\end{array}$ & Prospective case series & 10 & $\begin{array}{l}20 \mathrm{MHz} \\
\text { In vivo }\end{array}$ & $\begin{array}{l}67 \text { patients } \\
38 \mathrm{M}, 29 \mathrm{~F} \\
\text { Mean age } 68.7(28-85)\end{array}$ & $\begin{array}{l}75 \text { BCCs: various } \\
\text { subtypes including } \\
\text { superficial, nodular, } \\
\text { and invasive }\end{array}$ & NR & $\begin{array}{l}\text { Face, head } \\
\text { and neck, } \\
\text { trunk, limbs }\end{array}$ \\
\hline $\begin{array}{l}\text { Song 2014, South } \\
\text { Korea* }\end{array}$ & Prospective case series & 12 & $\begin{array}{l}17 \mathrm{MHz} \\
\text { In vivo }\end{array}$ & $\begin{array}{l}40 \text { patients } \\
15 \mathrm{M}, 25 \mathrm{~F} \\
\text { Mean age } 78.3(53-92)\end{array}$ & $\begin{array}{l}10 \text { BCCs: } \\
\text { most superficial and } \\
\text { nodular } \\
1 \text { morpheiform }\end{array}$ & NR & Face \\
\hline
\end{tabular}


Table 1 (continued)

\begin{tabular}{|c|c|c|c|c|c|c|c|}
\hline Study, country & Design & $\begin{array}{l}\text { QUADAS } \\
\text { score }\end{array}$ & $\begin{array}{l}\text { HFUS } \\
\text { maximum } \\
\text { frequency** }\end{array}$ & Population & BCC characteristics & $\begin{array}{l}\text { Primary, post- } \\
\text { treatment or } \\
\text { recurrence }\end{array}$ & $\begin{array}{l}\text { Location of } \\
\text { lesions }\end{array}$ \\
\hline Vilas-Sueiro 2018, Spain & Prospective case series & 12 & $\begin{array}{l}18 \mathrm{MHz} \\
\text { Ex vivo }\end{array}$ & $\begin{array}{l}65 \text { patients } \\
43 \mathrm{M}, 22 \mathrm{~F} \\
\text { Mean age } 76.36\end{array}$ & $58 \mathrm{BCCs}$ & NR & $\begin{array}{l}\text { Face, scalp, } \\
\text { trunk, limbs }\end{array}$ \\
\hline $\begin{array}{l}\text { Wenande 2020, } \\
\text { Denmark }\end{array}$ & Prospective case series & 12 & $\begin{array}{l}18 \mathrm{MHz} \\
\text { In vivo }\end{array}$ & $\begin{array}{l}19 \text { patients } \\
\text { M:F ratio } 3: 1 \\
\text { Mean age } 73(56-89)\end{array}$ & $\begin{array}{l}19 \text { BCCs: } \\
13 \text { nodular } \\
6 \text { superficial }\end{array}$ & Primary & $\begin{array}{l}\text { Face, scalp, } \\
\text { trunk, } \\
\text { extremities }\end{array}$ \\
\hline Wortsman 2010, Chile* & Retrospective case control & 9 & $\begin{array}{l}15 \mathrm{MHz} \\
\text { In vivo }\end{array}$ & 4,338 patients & $\begin{array}{l}41 \text { BCCs: } \\
37 \text { nodular } \\
4 \text { morpheiform }\end{array}$ & $\begin{array}{l}\text { Primary and } \\
\text { recurrences }\end{array}$ & NR \\
\hline Wortsman 2015, Chile & Retrospective case control & 11 & $\begin{array}{l}18 \mathrm{MHz} \\
\text { In vivo }\end{array}$ & $\begin{array}{l}31 \text { patients } \\
15 \mathrm{M}, 16 \mathrm{~F} \\
\text { Mean age } 67(35-92)\end{array}$ & $\begin{array}{l}31 \text { BCCs: } \\
16 \text { macronodular } \\
8 \text { nodular } \\
5 \text { morpheiform } \\
1 \text { adenoid cystic } \\
1 \text { sclerosing }\end{array}$ & Primary & $\begin{array}{l}\text { Face, scalp, } \\
\text { leg }\end{array}$ \\
\hline
\end{tabular}

M, male; F, female; NR, not reported; BCC, basal cell carcinoma. * Study reporting pooled data only of BCCs, along with other lesion types. ** Maximum frequency used in the study; however, some of the devices worked with variable frequency probes that allowed accesses to lower frequencies.

\section{Results}

Thirty articles were included in our systematic review (Table 1), studying a total of 1,203 biopsy-confirmed BCCs predominantly located on the head and neck. Nineteen studies reported the histologic variant of the lesions, with a total of 785 classified lesions. Of those, 452 (56.7\%) were nodular, 171 (21.8\%) superficial, 85 (10.8\%) infiltrative, 36 (4.6\%) mixed, 17 (2.2\%) morpheiform, and 32 (4.1\%) classified as others. Eighteen investigations included BCCs exclusively [19-36], 4 studied BCCs along with other lesion types but reported data separately for BCCs
[37-40], and 8 other studies reported pooled data of BCCs and other lesion types (eTable 2) [41-48]. Quality assessment revealed QUADAS scores ranging from 8 to 14 . Twelve of the 30 studies commented on operator training, of which 5 were radiologists, 4 were dermatologists, 1 was identified broadly as working in medical imaging, 1 was a physician without further specification, and the last one was a HFUS-trained medical school graduate. Only 7 of these studies quantified the operator's experience, ranging from $10 \mathrm{~h}$ of training to 15 years of experience. 
Table 2. Use of high-frequency ultrasound (HFUS) in determination of morphological characteristics of basal cell carcinomas (BCCs)

\begin{tabular}{|c|c|c|c|c|c|c|c|c|c|c|c|}
\hline & \multicolumn{4}{|l|}{ Size } & \multicolumn{5}{|l|}{ Depth } & \multirow[t]{2}{*}{ Margins } & \multirow[t]{2}{*}{ Invasion } \\
\hline & $\begin{array}{l}\text { US vs. } \\
\text { path }\end{array}$ & $\begin{array}{l}\text { US vs. } \\
\text { clinical }\end{array}$ & $\begin{array}{l}\text { Subtype } \\
\text { differences }\end{array}$ & Other & $\begin{array}{l}\text { US vs. } \\
\text { path }\end{array}$ & $\begin{array}{l}\text { US vs. path } \\
\text { vs. OCT }\end{array}$ & $\begin{array}{l}\text { US vs. } \\
\text { clinical }\end{array}$ & $\begin{array}{l}\text { Subtype } \\
\text { differences }\end{array}$ & Other & & \\
\hline Alfageme 2019 & & & $x$ & & & & & & & $\mathrm{x}$ & \\
\hline Ballester-Sanchez 2014 & & & & & $\mathrm{x}$ & & & & & & \\
\hline Bobadilla 2008 & & & & $\mathrm{x}$ & $x$ & & & & & $x$ & $\mathrm{x}$ \\
\hline Crisan 2013 & & & & & $x$ & & & & & & \\
\hline Desai 2007 & & $\mathrm{x}$ & & & & & $\mathrm{x}$ & & & $x$ & \\
\hline Goyal 2017 - A & & $x$ & & & & & $x$ & & & & \\
\hline Hernandez-Ibanez 2017 & & & & $x$ & & & & & $x$ & & \\
\hline Hinz 2012 & & & & & & $\mathrm{x}$ & & & & & \\
\hline Jambusaria-Pahlajani 2009 & & & & & & & & & & $x$ & \\
\hline Jovanovic 2005 & & & & & $\mathrm{x}$ & & & & & $\mathrm{x}$ & \\
\hline Khlebnikova 2018 & & & & & & & & $\mathrm{x}$ & & & \\
\hline Khlebnikova 2020 & & & & & $\mathrm{x}$ & & & & & & \\
\hline Lippert 2013 & & & & & & & & & $x$ & & \\
\hline Marmur 2010 & & $\mathrm{x}$ & & & & & & & & $\mathrm{x}$ & \\
\hline Mogensen 2009 & & & & & & $x$ & & & & & \\
\hline Nassiri-Kashani 2013 & $x$ & & & & $\mathrm{x}$ & & & & & & \\
\hline Pasquali 2016 & $x$ & & & & & & & & & $\mathrm{x}$ & \\
\hline Smucler 2012 & & & & & & & $\mathrm{x}$ & & & & \\
\hline Song 2014 & & & & $\mathrm{x}$ & $\mathrm{x}$ & & & & & & $\mathrm{x}$ \\
\hline Tormo 2014 & & & & & & & & & $\mathrm{x}$ & & \\
\hline Vilas-Sueiro 2018 & & & & & & & & & & $\mathrm{x}$ & \\
\hline Wang 2019 & & & & & & & & $\mathrm{x}$ & & $\mathrm{x}$ & \\
\hline Wortsman 2010 & & & & $x$ & & & & & $x$ & & $x$ \\
\hline
\end{tabular}

US, ultrasound; path, pathology; OCT, optical coherence tomography.

Morphological Characteristics: Surface Measurements, Depth, Margins, and Invasion

Twenty-three of the 30 articles included objectified surface measurements, thickness, margin delineation, and/or assessment of local invasion by HFUS, as detailed in Table 2.

\section{Surface Measurements}

Ten studies used HFUS to assess the size of BCCs (Table 3). Two studies compared lesion size on HFUS to measurements on histopathology $[29,46]$. Both of these showed larger measurements on HFUS. Three studies compared HFUS measurements of BCCs to clinical measurements $[22,39,41]$. One had larger HFUS measurements [22], one had comparable HFUS and clinical measurements [39], and one had smaller HFUS measurements [41]. Alfageme et al. used HFUS to identify sonographic features distinguishing invasive from noninvasive subtypes but did not identify a significant difference in size between these groups [19]. Hernandez-Ibañez et al. used US to assess BCC surface area to categorize the lesions as small or large ( $<$ or $\geq 40 \mathrm{~mm}^{2}$ ) for subsequent analyses [24]. Three other studies measured lesion dimensions on HFUS without further analysis [21, 47, 48].

Performance of HFUS for the Assessment of BCCs

\section{Depth}

Eighteen studies examined BCC depth using ultrasonography (Table 4). Seven groups exclusively compared HFUS depth measurements to histopathology. Of these, 1 reported negative results [20] while the other six found that ultrasound could offer an accurate representation of BCC thickness [21, 27, 29, 38, 44, 47]. Comparing HFUS vs. histopathology depth, five of the seven studies reported cases with HFUS slightly inferior thickness [20, 21, 29, $38,47]$, and the two others reported lesions with larger HFUS depth [27, 44]. Two studies investigated BCC thickness comparisons between HFUS, optical coherence tomography, and histopathology measurements [25, 45]. Both were found to overestimate thickness on HFUS in comparison to histopathology. Three studies compared US depth measurements to clinical estimates of tumor thickness [22, 31, 41]. Two of the total 18 studies measuring depth assessed BCC thickness to understand subtype differences better $[26,34]$. One study measured depth with HFUS to determine treatment parameters of high dose-rate brachytherapy [32]. Two studies measured lesion thickness to select BCCs appropriate for laser ablation pre-treatment followed by photodynamic therapy (PDT) $[28,31]$. Two other studies recorded depth measurements with HFUS but did not elaborate $[24,48]$. 
Table 3. Use of high-frequency ultrasound (HFUS) in size measurement determination of basal cell carcinomas (BCCs)

\begin{tabular}{|c|c|c|c|}
\hline & Study & Gold standard & Results \\
\hline \multirow[t]{2}{*}{ US vs. path } & $\begin{array}{l}\text { Nassiri-Kashani } \\
2013\end{array}$ & Full excision & $\begin{array}{l}\text { Width statistically larger on US than on histopathology, low correlation reported for } \\
\text { diameter }(r=0.27) \text {. Largest diameter mean: US 5,996.77 } \pm 2,271.783 \mu \mathrm{m} \text {, pathology } \\
3,891.07 \pm 1,995.452 \mu \mathrm{m}\end{array}$ \\
\hline & Pasquali 2016** & Full excision & $\begin{array}{l}100 \text { skin lesions ( } 79 \text { BCCs, pooled data) } \\
\text { Ex vivo vs. histology tumor area: moderate correlation }\left(r^{2}=0.4940\right) \\
\text { Ex vivo vs. in vivo tumor area: moderate correlation }\left(r^{2}=0.5524\right) \\
\text { All measurements obtained histologically tend to be smaller than on HFUS }\end{array}$ \\
\hline \multirow[t]{3}{*}{$\begin{array}{l}\text { US vs. } \\
\text { clinical }\end{array}$} & Desai 2007 & Clinical & 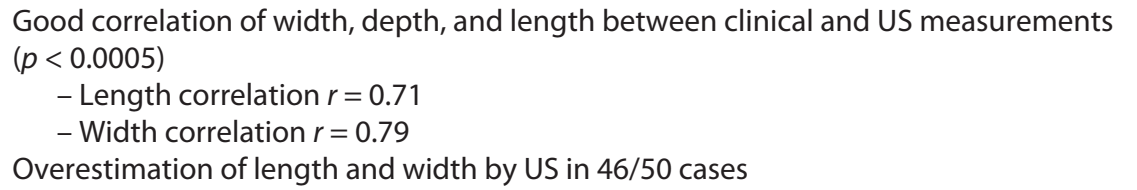 \\
\hline & Goyal $2017-$ A & US & $\begin{array}{l}\text { A statistically significant difference between clinical and US measurements ( } 20 \text { NMSCs, } \\
17 \text { BCCs pooled data) was observed for the second largest diameter }(p=0.03) \text {, but not } \\
\text { for the largest diameter ( } p=0.24) \\
\text { - Largest diameter mean: clinical } 7.55 \mathrm{~mm} \text {, US } 5.79 \mathrm{~mm}(p=0.24) \\
\text { - Second largest diameter mean: clinical } 6.3 \mathrm{~mm}, \text { US } 4.02 \mathrm{~mm}(p=0.03) \\
\text { - Depth mean: clinical } 0.95 \mathrm{~mm} \text {, US } 1.76 \mathrm{~mm}(p=0.02)\end{array}$ \\
\hline & Marmur 2010 & Clinical & $\begin{array}{l}\text { No statistically significant difference for length or width. US identified smaller } \\
\text { diameters for BCCs but larger for SCCs than clinically } \\
\text { Width mean: clinical } 0.81 \mathrm{~mm} \text {, US } 0.62 \mathrm{~mm}(t=-1.324, p=0.20) \\
\text { Length mean: clinical } 0.85 \mathrm{~mm} \text {, US } 0.70 \mathrm{~mm}(t=-1.093, p=0.29)\end{array}$ \\
\hline $\begin{array}{l}\text { Subtype } \\
\text { differences }\end{array}$ & Alfageme 2019 & - & $\begin{array}{l}\text { Size of infiltrative vs. non-infiltrative BCCs were compared, no significant difference } \\
\text { between groups } \\
\text { Max BCC diameter for infiltrative } 7.65 \pm 2.1 \mathrm{~mm} \text { vs. non-infiltrative } 7.25 \pm 2.3 \mathrm{~mm}(p= \\
0.34 \text { ) }\end{array}$ \\
\hline \multirow[t]{4}{*}{ Other } & $\begin{array}{l}\text { Hernandez-lbanez } \\
2017\end{array}$ & - & $\begin{array}{l}\text { US measured surface area to classify lesions as small or large }\left(<\text { or } \geq 40 \mathrm{~mm}^{2}\right) \\
\text { Mean measurements of } 8.2 \pm 4.5 \mathrm{~mm} \times 6.1 \pm 3 \mathrm{~mm} \\
\text { Mean surface area of } 60.42 \pm 71.02 \mathrm{~mm}^{2} ; \text { median } 40 \mathrm{~mm}^{2}\end{array}$ \\
\hline & Wortsman 2010 & - & Lesion measurements obtained but not reported \\
\hline & Bobadilla 2008 & - & Lesion measurements obtained but not reported \\
\hline & Song 2014 & - & Lesion measurements obtained but not reported \\
\hline
\end{tabular}

US, ultrasound; path, pathology; OCT, optical coherence tomography; BCC, basal cell carcinoma. ** Includes ex vivo assessment.

\section{Lateral Margins}

Nine studies investigated the margins of BCCs with ultrasound (Table 5) $[19,21,22,33,34,39,43,44,46]$. Six of these articles explored BCC margins in the context of surgical treatment $[22,33,39,43,44,46]$, of which two did so in ex vivo specimens $[33,46]$. Two authors briefly commented on margins as a reflection of tumor shape $[21,44]$. Lastly, two studies attempted to use BCC margin characteristics to distinguish subtypes $[19,34]$.

\section{Invasion of Adjacent Structures}

Three of the 30 studies included used HFUS to assess for adjacent structure invasion (Table 6) $[21,47,48]$, specifically ruling out the invasion of cartilage.

\section{Detection and Characterization}

Eleven studies explored the diagnostic role of HFUS in detecting BCCs, their specific subtypes, or subclinical lesions, as outlined in Table 7 . These studies were not intended to perform a primary diagnosis of BCC because the lesions were first evaluated clinically, then sent to the 
Table 4. Use of high-frequency ultrasound (HFUS) in depth measurement determination of basal cell carcinomas (BCCs)

\begin{tabular}{|c|c|c|c|}
\hline & Study & Gold standard & Results \\
\hline \multirow[t]{7}{*}{ US vs. path } & Ballester-Sanchez 2014 & Punch biopsy & $\begin{array}{l}\text { No significant association between US and histology. Nodular cases present larger depth } \\
\text { differences than superficial BCCs - HFUS found to be less accurate when lesions are very } \\
\text { superficial } \\
\text { Mean superficial BCC US thickness: } 0.32 \mathrm{~mm} \text { (range } 0.1-1.3 \text { ) } \\
\text { Mean superficial BCC Breslow depth: } 0.77 \mathrm{~mm} \text { (range } 0.3-1.9 \text { ) } \\
\text { Mean nodular BCC US thickness: } 1.71 \mathrm{~mm} \text { (range 0.1-3.7) } \\
\text { Mean nodular BCC Breslow thickness: } 2.09 \mathrm{~mm} \text { (range 1.1-3.1) }\end{array}$ \\
\hline & Bobadilla 2008 & Full excision & $\begin{array}{l}\text { Excellent correlation }(I C C=0.9) \text { between US and histology in } 27 / 29 \text { cases } \\
\text { Mean US thickness: } 3.7 \pm 1.1 \mathrm{~mm} \text { (range } 1.1-5.0) \\
\text { Mean histology thickness: } 3.9 \pm 1.0 \mathrm{~mm} \text { (range } 1.1-5.2)\end{array}$ \\
\hline & Crisan 2013 & Full excision & $\begin{array}{l}\text { A strong correlation ( } 98.4 \%) \text { between US thickness and histological thickness for nodular BCCs } \\
\text { Mean US depth: } 1.27 \pm 0.6 \mathrm{~mm} \\
\text { Mean histology depth: } 1.43 \pm 0.7 \mathrm{~mm}\end{array}$ \\
\hline & Jovanovic 2005 & Full excision & $\begin{array}{l}\text { Correlation between depth by US and depth by histopathology after excision was very high ( } r= \\
\text { 0.98) } \\
\text { In comparison to thickness on histology, tumor thickness obtained by US ( } n=35,12 \text { BCCs pooled } \\
\text { data): } \\
\quad \text { - overestimated in } 29 / 35 \text { cases (absolute value: } 0.01 \text { to } 0.9 \mathrm{~mm} \text { and relative value: } 0.4 \% \text { to } \\
62 \% \text { ) } \\
\text { - equal in } 3 / 35 \text { cases } \\
\text { - underestimated in } 3 / 35 \text { cases (absolute value: } 0.11 \text { to } 0.51 \mathrm{~mm} \text { and relative value: } 8 \% \text { to } \\
\quad 42 \% \text { ) }\end{array}$ \\
\hline & Khlebnikova 2020 & $\begin{array}{l}\text { Excision or } \\
\text { punch biopsy }\end{array}$ & $\begin{array}{l}27 \text { BCCs scanned at both } 30 \mathrm{MHz} \text { and } 75 \mathrm{MHz} \text {. Lesions subsequently excised or punch biopsied } \\
\text { and divided into thin }(<1 \mathrm{~mm}) \text { and thick }(>1 \mathrm{~mm}) \text { groups according to depth on histopathology } \\
\text { Thin group: } \\
\text { - no statistical difference between US and histology depth for both } 75 \mathrm{MHz}(p=0.78) \text { and } 30 \\
\mathrm{MHz}(p=0.339) \\
\text { - high correlation for } 75 \mathrm{MHz}(r=0.870) \text { and weak correlation for } 30 \mathrm{MHz}(r=0.339) \\
\text { Thick group: } \\
\text { - no statistical difference observed between US } 30 \mathrm{MHz} \text { and histology depth }(p=0.882) \text { with a } \\
\text { very high correlation }(r=0.951) \\
\text { - US evaluation at } 75 \mathrm{MHz} \text { uninterpretable for many cases (lateral and lower boundaries not } \\
\text { identified) }\end{array}$ \\
\hline & Nassiri-Kashani 2013 & Full excision & $\begin{array}{l}\text { No statistical difference in tumor depth between US and histology with a moderate correlation }(r \\
=0.45) \\
\text { Mean US depth: } 1,353.68 \pm 656.45 \mu \mathrm{m} \\
\text { Mean histopathology depth: } 1,560.71 \pm 1,044.32 \mu \mathrm{m}\end{array}$ \\
\hline & Song 2014 & Full excision & $\begin{array}{l}\text { Excellent correlation (ICC } 0.953 \text { ) for US and histology of all lesions, very good correlation (ICC } 0.89) \\
\text { for the } 10 \text { BCCs exclusively as calculated per Table } 3 \text { measurements available } \\
\text { Mean US depth: } 3.97 \pm 3.15 \mathrm{~mm} \text { (range } 0.80-14.00) \\
\text { Mean histological depth: } 4.04 \pm 2.92 \mathrm{~mm} \text { (range } 1.00-14.00)\end{array}$ \\
\hline \multirow[t]{2}{*}{$\begin{array}{l}\text { US vs. path } \\
\text { vs. OCT }\end{array}$} & Hinz 2012 & Full excision & $\begin{array}{l}\text { Moderate correlation (ICC 0.59) for US and histology; higher correlation (ICC 0.83) for OCT and } \\
\text { histology } \\
\quad \text { - Both HFUS and OCT measurements were statistically similar to measurements on } \\
\quad \text { histopathology, per our analyses of paired T-tests comparing measurements available in Table } \\
\quad 1 \\
\text { Mean US depth: } 1.03 \pm 0.51 \mathrm{~mm} \text { (range } 0.30-2.10 \text { ) } \\
\text { Mean histopathology depth: } 0.82 \pm 0.46 \mathrm{~mm} \text { (range } 0.15-1.50 \text { ) } \\
\text { Overestimation of depth on HFUS (in comparison to histopath); underestimation of depth on OCT } \\
\text { (in comparison to histopath) }\end{array}$ \\
\hline & Mogensen 2009 & Punch biopsy & $\begin{array}{l}\text { Overestimation of depth was found with US with a significant difference observed between US } \\
\text { and histology }(n=34,23 \text { BCCs pooled data) } \\
\text { Mean US depth: } 1,552 \pm 722 \mu \mathrm{m} \\
\text { Mean histopathology depth: } 821 \pm 470 \mu \mathrm{m}\end{array}$ \\
\hline
\end{tabular}


Table 4 (continued)

\begin{tabular}{|c|c|c|c|}
\hline & Study & Gold standard & Results \\
\hline \multirow[t]{3}{*}{$\begin{array}{l}\text { US versus } \\
\text { clinical }\end{array}$} & Desai 2007 & Full excision & $\begin{array}{l}\text { Clinical and US measurements correlated well in terms of depth }(p>0.0005) \\
\text { Lesion measurements obtained but not reported }\end{array}$ \\
\hline & Goyal 2017 - A & Punch biopsy & $\begin{array}{l}\text { Depth obtained with US was significantly different from clinical estimates }(p=0.02) \text {. Clinical } \\
\text { measurements were found to underestimate the depth of the lesion compared to US ( } 20 \text { NMSCs, } \\
17 \text { BCCs pooled data) } \\
\text { Mean US depth: } 1.76 \pm 1.28 \mathrm{~mm} \\
\text { Mean clinical depth: } 0.95 \pm 1.10 \mathrm{~mm}\end{array}$ \\
\hline & Smucler 2012 & US & $\begin{array}{l}75 \text { BCCs were divided according to tumor depth on HFUS into one of three groups: A) }<2 \mathrm{~mm}, \mathrm{~B} \text { ) } \\
2-3 \mathrm{~mm} \text {, and C) }>3 \mathrm{~mm} \text {. Each group had specific treatment protocols } \\
\text { ** US measurements are considered as the gold standard and are compared to clinical depth } \\
\text { estimated by an experienced dermatologist** } \\
\text { Clinical assessment of depth was incorrect compared to US in } 10 / 75 \text { lesions } \\
\text { Lesion measurements obtained but not reported }\end{array}$ \\
\hline \multirow[t]{2}{*}{$\begin{array}{l}\text { Subtype } \\
\text { differences }\end{array}$} & Khlebnikova 2018 & - & $\begin{array}{l}\text { Statistically significant increase in mean depth of nodular and morpheiform variants compared to } \\
\text { superficial BCCs }(p<0.05) \\
\text { Mean US depth superficial BCC: } 556.28 \pm 136.95 \mu \mathrm{m} \\
\text { Mean US depth nodular BCC: } 2,439.71 \pm 865.92 \mu \mathrm{m} \\
\text { Mean US depth morpheiform BCC: } 1,500 \pm 325.33 \mu \mathrm{m}\end{array}$ \\
\hline & Wang 2019 & - & $\begin{array}{l}\text { Low-risk and high-risk lesions exhibited a significant difference in depth. Lesion measurements } \\
\text { obtained but not reported }\end{array}$ \\
\hline \multirow[t]{4}{*}{ Other } & Tormo 2014 & - & Median US depth: 2 mm (range 0-4) \\
\hline & Lippert 2013 & - & Lesion measurements obtained but not reported \\
\hline & Hernandez-Ibanez 2017 & & Lesion measurements obtained but not reported \\
\hline & Wortsman 2010 & - & Lesion measurements obtained but not reported \\
\hline
\end{tabular}

US, ultrasound; path, pathology; OCT, optical coherence tomography; BCC, basal cell carcinoma; AK, actinic keratosis.

ultrasound examination, and finally confirmed on pathology.

Two studies evaluated the performance of HFUS to detect the location and characteristics of the primary tumors [40,48]. Three investigations either sought to identify specific BCC subtypes with the help of HFUS $[26,37]$ or described sonographic characteristics of subtypes [22]. Five studies aimed to find sonographic differences between low-risk and high-risk subtypes of BCCs [19, 23, $24,34,36]$. Subclinical discrete or contiguous BCCs were identified on HFUS in three different studies [21, 34, 48].

Hyperechoic spots were very informative to stratify BCCs by severity and to identify certain specific subtypes. More than 3 hyperechoic spots located both centrally and in the periphery were identified to be characteristic of nodular BCCs, and more than seven hyperechoic spots were used as a cut-off for identifying high-risk of recurrence BCCs [26, 37]. Further, marginal stiffness was found to be a feature of infiltrative BCCs [19]. Other studies identified irregular shape and subcutaneous tissue in- volvement as characteristic of high-risk BCCs [34]. Five different studies explored the diagnostic value of hyperechoic spots $[19,26,34,36,40]$, but only one described a systematic approach to counting them [36].

\section{Management}

Eleven of the 30 studies, detailed in Table 8, used HFUS to manage BCCs, either for planning surgical or non-surgical treatment or monitoring response to treatment. Ultrasound modified surgical planning in three studies by identifying satellite lesions, by ruling out the presence of cartilage invasion $[21,47]$, or by using HFUS to outline depth, height, and width [22, 47], which subsequently guided reconstructive options. Desai et al.'s excision with 4-mm margins on HFUS-delineated BCCs resulted in a $10 \%$ margin positivity rate [22], which is in line with prior studies showing tumor clearance rates of $92 \%$ with clinically outlined BCCs [49]. It is argued that HFUS may not have been used to its full potential in this study as the 5 lesions with positive margins presented sonographic 
Table 5. Use of high-frequency ultrasound (HFUS) in margin assessment of basal cell carcinomas (BCCs)

\begin{tabular}{|c|c|c|c|}
\hline & Study & $\begin{array}{l}\text { Used for } \\
\text { excision }\end{array}$ & Results \\
\hline \multirow{6}{*}{$\begin{array}{l}\text { In context of } \\
\text { surgical } \\
\text { treatment }\end{array}$} & Desai 2007 & US & $\begin{array}{l}\text { Margin assessment consistently showed a mean } 20 \% \text { to } 25 \% \text { increase compared to clinical measurements } \\
(p<0.0005)\end{array}$ \\
\hline & $\begin{array}{l}\text { Jambusaria- } \\
\text { Pahlajani } 2009\end{array}$ & Clinical & $\begin{array}{l}\text { Tumor map generated outlining peripheral margins of lesions on US assessment pre-Mohs (test) and } \\
\text { overlaid with the histopathology tumor map post first stage of Mohs (gold standard) ( } n=98,77 \text { BCCs } \\
\text { pooled data) } \\
\text { - Sensitivity } 32 \% \text {, specificity } 88 \% \text {, PPV } 47 \% \text {, and NPV } 79 \% \text {, correct classification } 73 \% \text { for US delimitation } \\
\text { of margins compared to tumor map from histopathology } \\
\text { - Sensitivity } 80 \%\left(95 \% \mathrm{Cl} 28-99 \text { ) and specificity } 84 \%(95 \% \mathrm{Cl} 69-94) \text { for larger tumors (area }>1.74 \mathrm{~cm}^{2} \text { ) }\right. \\
\text { with histologically positive margins only in the dermis }\end{array}$ \\
\hline & Marmur 2010 & Clinical & $\begin{array}{l}\text { Margins delineated clinically (used for Mohs) and assessed by US in } 9 \text { BCCs } \\
-4 \text { BCCS required multiple stages: all had smaller size on US than clinically } \\
-2 \text { BCCs required } 1 \text { stage of Mohs but assessed as larger on US than clinically } \\
-3 \text { BCCs required } 1 \text { stage of Mohs but assessed as smaller on US than clinically }\end{array}$ \\
\hline & Jovanovic $2005^{\dagger}$ & US & Tumor margins on US correlated very well with histopathology \\
\hline & Pasquali $2016^{* *}$ & US & $\begin{array}{l}\text { Margins assessed pre and post excision on HFUS and compared to histology ( } 84 \text { NMSC, } 79 \text { BCCs pooled data): } \\
-81 \text { had a correspondence between ex vivo HFUS and histology margins ( } 77 \text { negative SM, } 4 \text { positive } \\
\text { SM on both ex vivo HFUS and histology) } \\
-2 \text { had negative SM by ex vivo HFUS while positive SM by histology (i.e., incorrect US) } \\
-1 \text { indeterminate scan }\end{array}$ \\
\hline & $\begin{array}{l}\text { Vilas-Sueiro } \\
2019^{* *}\end{array}$ & Clinical & $\begin{array}{l}\text { Excisions with 2-3 mm margins assessed clinically. Ex vivo specimen examined by HFUS prior to } \\
\text { histopathology showed: } \\
\quad \text { - Lateral margins: mean } 1.61 \mathrm{~mm} \text { (range } 0-3.8 \mathrm{~mm} \text { ) } \\
\quad \text { - Deep margins: } 2.05 \mathrm{~mm} \text { (range } 0-5.7 \mathrm{~mm} \text { ) } \\
\text { Ability to predict margin involvement: specificity } 91.66 \% \text { and NPV } 96 \%\end{array}$ \\
\hline \multirow[t]{2}{*}{ Tumor shape } & Bobadilla 2008 & - & Tumor-free borders on histology in $100 \%$ of cases after full excision guided by US \\
\hline & Jovanovic $2005^{\dagger}$ & - & Tumor shape on US correlated very well with histopathology \\
\hline \multirow{2}{*}{$\begin{array}{l}\text { Subtype } \\
\text { differences }\end{array}$} & Wang 2019 & - & High risk and low risk BCC US margins did not differ significantly $\left(x^{2}=3.231, p=0.072\right)$ \\
\hline & Alfageme 2019 & - & $\begin{array}{l}\text { Increased marginal stiffness was statistically greater in infiltrative BCCs }(88 \%) \text { than non-infiltrative (19\%). } \\
\text { Study characteristics for marginal stiffness of: } \\
\quad \text { - infiltrative BCC: sensitivity } 89 \% \text {, specificity } 82 \% \text {, PPV } 67 \% \\
\text { - non-infiltrative BCCs: NPV } 95 \%\end{array}$ \\
\hline
\end{tabular}

US, ultrasound; HFUS; high-frequency ultrasound; PPV, positive predictive value; NPV, negative predictive value; BCC, basal cell carcinoma; NMSC, nonmelanoma skin cancer; SCC, squamous cell carcinoma; SM, surgical margin. ${ }^{* *}$ Includes ex vivo assessment. ${ }^{\dagger}$ Study appearing twice in table.

findings that could have prompted a referral to Mohs (unclear boundaries and asymmetric growth patterns) instead of going forward with the excision [22].

Four studies used ultrasound to either select the best treatment for BCCs or to choose optimal parameters of a given non-surgical treatment. Two of these did so with brachytherapy $[32,41]$. Ultrasound proved to be accurate to assess tumor dimensions and to inform the prescription parameters for brachytherapy $[32,41]$. Excellent clearance rates were reported, compatible with previous studies showing local control rates of $98.7 \%$ for
eBT-treated NMSC [50]. The main advantage of US was to minimize toxicity by having an objective measurement keeping the prescription depth at a strict minimum. Toxicity for both studies was $\leq$ grade 1 in $100 \%$ of patients $[32,41]$, while a prior eBT study assessing 154 NMSC of which 149 were BCCs reported only $52.6 \%$ grade $0-1$ acute radiation dermatitis and $94.62 \%$ grade 0-1 late toxicity [50]. Two studies treated BCCs with PDT regimens and used HFUS to optimally select parameters or adjunct treatments $[28,31]$. Both studies included in our review aimed to identify optimal treat- 
Table 6. Use of high-frequency ultrasound (HFUS) in assessment of invasion of adjacent structures by basal cell carcinomas (BCCs)

\begin{tabular}{|c|c|c|}
\hline Study & $\begin{array}{l}\text { Adjacent structures } \\
\text { examined }\end{array}$ & Results \\
\hline Bobadilla 2008 & Cartilage & $\begin{array}{l}16 \text { out of } 29 \text { BCCs assessed for invasion of the nasal cartilage } \\
\text { - None showed signs of tumor involvement in the cartilage on HFUS } \\
\text { - Influenced the decision to not remove any cartilage, pathology later confirmed margins } \\
\text { were tumor free }\end{array}$ \\
\hline Wortsman 2010 & NR & $\begin{array}{l}41 \text { BCCs, distance between lesions and surrounding structures was recorded } \\
- \text { No specific mention of invasion or absence thereof is made when reporting the findings }\end{array}$ \\
\hline
\end{tabular}

Table 7. High-frequency ultrasound (HFUS) diagnostic applications for detection and characterization of basal cell carcinomas (BCCs)

\begin{tabular}{|c|c|c|}
\hline & Study & Results \\
\hline Detection & Uhara 2007 & $\begin{array}{l}29 \text { BCCs and } 56 \text { melanomas were classified into } 4 \text { patterns of } H S: A=\text { multiple }>5 \text { spots, } B=\text { sparse } 3-5 \text { spots, } C= \\
\text { multiple moderate, } D=\text { sparse moderate } \\
\quad-\text { BCCs: } 14 / 29 \text { A; } 7 / 29 B ; 3 / 29 \text { C; } 5 / 29 \text { D. All superficial BCCs (3/29) were pattern D } \\
\text { - Melanomas: 0/56 A, B, C; 3/56 D } \\
\text { - HS correlated with calcifications, cornified cysts, or clusters of apoptotic cells on histopathology }\end{array}$ \\
\hline \multirow[t]{2}{*}{$\begin{array}{l}\text { Individual subtype } \\
\text { identification }\end{array}$} & Bens 2015 & $\begin{array}{l}\text { Retrospective examination of US scans of lesions where there was hesitancy in clinical diagnosis between nodular BCC } \\
\text { and sebaceous hyperplasia ( } n=77 \text { of which } 33 \text { BCCs) } \\
\quad \text { - Echogenicity was qualitatively recorded for each lesion (hypoechoic vs. iso/hyperechoic) } \\
\quad \rightarrow \text { hypoechogenicity established as diagnostic criteria for BCCs } \\
\text { - Sensitivities of } 90.9 \% \text { for nodular BCCs and } 81.3 \% \text { for infiltrative BCCs reported }\end{array}$ \\
\hline & Desai 2007 & $\begin{array}{l}\text { Study included clinically appearing nodular and superficial BCCs } \\
-2 \text { BCCs resulted as morpheiform and infiltrative on histopathology. This was strongly suspected on HFUS as } \\
\text { strikingly different patterns were noted and boundaries seemed unclear } \\
\text { - Ultrasonographic findings described for morpheiform, infiltrative, superficial, and nodular BCCs }\end{array}$ \\
\hline
\end{tabular}


Table 7 (continued)

\begin{tabular}{|c|c|c|}
\hline & Study & Results \\
\hline \multirow[t]{4}{*}{$\begin{array}{l}\text { Low-risk vs. high- } \\
\text { risk classification }\end{array}$} & $\begin{array}{l}\text { Alfageme } \\
2019\end{array}$ & $\begin{array}{l}\text { Characterization of infiltrative }(22 / 31) \text { vs. non-infiltrative }(9 / 31) \text { BCCs using elastography. Statistically greater strain } \\
\text { ratios (marginal stiffness) were recorded at the periphery of infiltrative compared to non-infiltrative BCCs: } \\
\text { - Sensitivity } 89 \% \text {, specificity } 82 \% \text {, PPV } 67 \% \text {, and NPV } 95 \% \text { for non-infiltrative BCCs } \\
\text { - Size, vascularization, or hyperechoic dots were not significantly different between the } 2 \text { groups }\end{array}$ \\
\hline & $\begin{array}{l}\text { Hernandez- } \\
\text { Ibanez } 2014\end{array}$ & $\begin{array}{l}\text { Assessment of } 8 \text { clinically suspected recurrences in non-surgically treated BCCs. Each suspected recurrence was } \\
\text { scanned, then punch biopsied and finally excised. US appearance classified as aggressive vs. non-aggressive lesions, } \\
\text { then classification compared to histopathology: } \\
\text { - US correctly identified } 4 / 5 \text { infiltrative BCCs but } 0 / 2 \text { superficial BCCs } \\
\text { - One lesion was non neoplastic but identified as non-aggressive on US }\end{array}$ \\
\hline & $\begin{array}{l}\text { Hernandez- } \\
\text { Ibanez } 2017\end{array}$ & $\begin{array}{l}156 \text { BCCs were scanned, then punch biopsied, and finally excised. US appearance classified as invasive vs. non-invasive, } \\
\text { then classification was compared between HFUS and excision histopathology as well as between punch and excision } \\
\text { histopathology: } \\
\text { - Agreement with excision was } 73.7 \% \text { for US and } 79.9 \% \text { for punch biopsy } \\
\text { - US sensitivity } 74.5 \% \text { and specificity } 73 \% \text { vs. punch biopsy sensitivity } 76 \% \text { and specificity } 82 \% \text { for detection of } \\
\text { invasive lesions } \\
\text { - Subtype analysis: Sensitivity with punch biopsy was better for nodular BCCs. US was more specific and better PPV } \\
\text { (US } 93.3 \% \text { vs. punch biopsy } 92 \%) \text { for superficial BCCs } \\
\text { Subtype identification based on surface area of lesions: } \\
\text { - Small BCCs }\left(<40 \mathrm{~mm}^{2}\right) \text { : agreement with excision was } 70.4 \% \text { for US and } 86.4 \% \text { for punch biopsy } \\
\text { - Large BCCs }\left(>40 \mathrm{~mm}^{2}\right) \text { : agreement with excision was } 77.3 \% \text { for US and } 72.6 \% \text { for punch biopsy } \\
\text { - As lesions got larger, diagnostic ability of US improved while that of punch biopsy decreased } \\
\text { Mixed subtypes lesions: } \\
\text { - High NPV (>95\%) for both US and punch biopsy } \\
\text { - Punch biopsy better than US for PPV, sensitivity, and specificity }\end{array}$ \\
\hline & Wang 2019 & $\begin{array}{l}\text { Review of } 46 \text { BCC US scans ( } 6 \text { high-risk and } 40 \text { low-risk). Multiple parameters were described per specific BCC subtype } \\
\text { and subsequently compared to see if any of these parameters would be discriminant between low-risk vs. high-risk } \\
\text { lesions } \\
\text { - US identified high-risk lesions with irregular shapes and infiltration into the subcutaneous tissue } \\
\text { - No significant difference observed to classify high-risk vs. low-risk lesions based on HS since } 76 \% \text { of BCCs } \\
\text { displayed them }\end{array}$ \\
\hline \multirow[t]{3}{*}{ Subclinical lesions } & $\begin{array}{l}\text { Bobadilla } \\
2008\end{array}$ & 2 satellite lesions on nose were identified by US in a patient with 1 clinically visible BCC ( $n=29$ BCCs) \\
\hline & Wang 2019 & $\begin{array}{l}5 \text { subclinical lesions were identified on US out of } 46 \text { BCCs: } \\
-1 \text { discrete: micro-nodular } \\
-4 \text { contiguous: } 3 \text { nodular and } 1 \text { mixed nodular and sclerosing }\end{array}$ \\
\hline & $\begin{array}{l}\text { Wortsman } \\
2010\end{array}$ & 2 satellite lesions were identified on US out of 41 BCCs \\
\hline
\end{tabular}

HS, hyperechoic spots; US, ultrasound; HFUS, high-frequency ultrasound; PPV, positive predictive value; NPV, negative predictive value. 
Table 8. High-frequency ultrasound (HFUS) management applications for basal cell carcinomas (BCCs)

\begin{tabular}{|c|c|c|}
\hline & Study & Results \\
\hline \multirow[t]{3}{*}{ Surgical planning } & Bobadilla 2008 & $\begin{array}{l}27 \text { clinical BCCs examined, one of which had } 2 \text { subclinical lesions found by US } \rightarrow \text { change of surgical plan to a } \\
\text { frontal flap to excise all } 3 \text { lesions } \\
\text { - Cartilage involvement of the nose ruled out by US } \\
\text { - Depth of all the incisions was guided with US evaluation }\end{array}$ \\
\hline & Desai 2007 & $\begin{array}{l}\text { Depth, height, and width of } 50 \text { BCCs were outlined by US and excised with } 4 \mathrm{~mm} \text { margins. 5/50 had positive } \\
\text { margins } \\
\quad-2 \text { nodular, } 1 \text { superficial, } 1 \text { morpheiform, and } 1 \text { infiltrative } \\
- \text { All } 5 \text { were located on masked area of face (increased scanning difficulty) }\end{array}$ \\
\hline & Song 2014 & $\begin{array}{l}47 \text { skin lesions (10 BCCs, pooled data) scanned by US prior to surgical excisions ( } 3-5 \mathrm{~mm} \text { margins) } \\
\text { - Local invasion of cartilage ruled out } \\
\text { - Depth and size identified by US were used to choose reconstructive options } \\
\text { - Unclear how many of the } 10 \text { BBCs had positive margins but mention that } 1 \text { morpheiform BCC was not cleared } \\
\text { with } 4 \mathrm{~mm} \text { margins }\end{array}$ \\
\hline $\begin{array}{l}\text { Non-surgical } \\
\text { planning - } \\
\text { brachytherapy (BT) }\end{array}$ & Tormo 2014 & $\begin{array}{l}45 \text { BCCs assessed by HFUS to determine depth } \\
\text { - US used for prescription depth for HDR-BT ( }<3 \mathrm{~mm} \text { or between } 3 \text { and } 4 \mathrm{~mm} \text { ) } \\
98 \% \text { complete regression at } 47 \text { months; toxicity was at most grade } 1 \\
\text { Lesions } \geq 4 \mathrm{~mm} \text { were excluded as to not exceed acceptable radiation doses }\end{array}$ \\
\hline $\begin{array}{l}\text { Non-surgical } \\
\text { planning - } \\
\text { photodynamic } \\
\text { therapy (PDT) }\end{array}$ & Lippert 2013 & $\begin{array}{l}\text { Aimed to assess the efficacy of ablative fractional photothermolysis (AFP) as an adjunct to PDT for nodular BCCs } \\
\text { thicker than } 2 \mathrm{~mm} \text {. US was used to: } \\
\quad \text { - assess eligibility of BCCs for LA + PDT ( }<2 \mathrm{~mm} \text {; control) vs. LA + AFP + PDT ( }>2 \mathrm{~mm} \text {; test) } \\
\text { - assess laser ablation depth } \\
\text { Laser ablation + PDT had clearance rate of } 80.4 \% \text { vs. } 92.9 \% \text { for laser ablation + AFP + PDT at } 18 \text { months; toxicity was } \\
\text { at most grade } 1\end{array}$ \\
\hline \multirow[t]{3}{*}{ Monitoring } & Goyal 2017 - B & $\begin{array}{l}\text { US was used to: } \\
\text { - assess lesions pre and post eBT treatment to monitor recurrences at } 6 \text { months } \\
\text { - distinguish residual disease from post eBT inflammatory changes } \\
\text { At follow-up: } \\
\text { - Clinically, there was no apparent lesion } \\
\text { - On US, } 11 / 14 \text { NMSCs ( } 6 / 9 \text { BCCs) showed no residual disease and } 3 / 14 \text { NMSCs ( } 3 / 9 \text { BCCs) were reduced in size. } \\
\text { Specific measurement improvements are provided for each PR patient. These } 3 \text { cases were followed up more } \\
\text { closely by the treating radiation oncologist and dermatologist }\end{array}$ \\
\hline & $\begin{array}{l}\text { Hernandez- } \\
\text { Ibanez } 2014\end{array}$ & $\begin{array}{l}\text { US and punch biopsy were compared to excisional biopsy to study recurrences in } 8 \text { BCCs post treatment (non- } \\
\text { surgical) and to classify aggressivity of lesion } \\
\quad \text { - US correctly identified } 4 / 5 \text { infiltrative and } 0 / 2 \text { superficial BCCs } \\
\text { - Punch biopsy correctly identified: } 1 / 5 \text { infiltrative and } 2 / 2 \text { superficial BCCs }\end{array}$ \\
\hline & Wenande 2020 & $\begin{array}{l}\text { US, OCT, and RCM were compared in monitoring of response to treatment of } 19 \text { BCCs with combined AFP and dual } \\
\text { topical chemotherapeutic agents } \\
\text { Follow-ups at } 30 \text { days and } 3 \text { months both showed that HFUS was not helpful for differentiating clearance vs. } \\
\text { residual disease compared to OCT and RCM }\end{array}$ \\
\hline
\end{tabular}




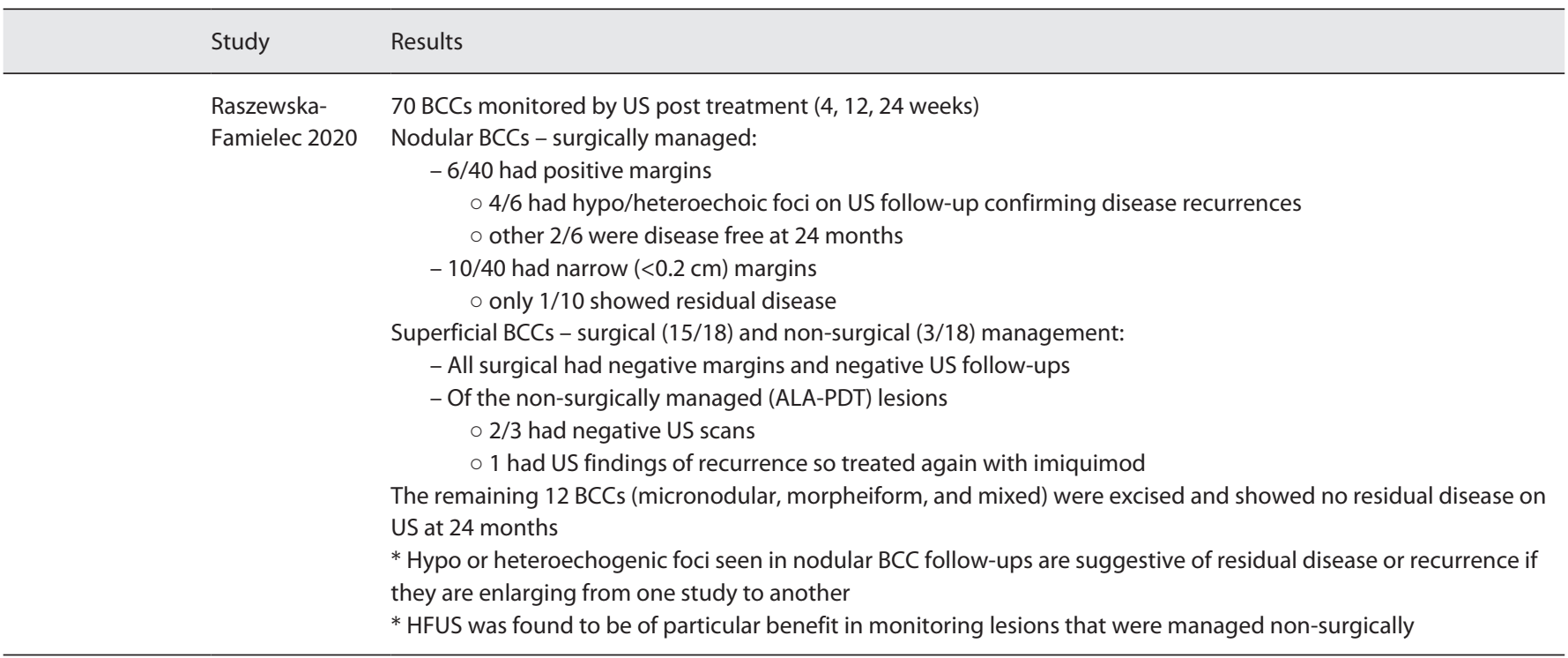

US, ultrasound; HDR-BT, high dose rate brachytherapy; LA, laser ablation; PDT, photodynamic therapy; AFP, ablative fractional photothermolysis; eBT, electronic brachytherapy; OCT, optical coherence tomography; RCM, reflectance confocal microscopy.

ments for thicker BCCs $[28,31]$, considering that current evidence suggests that PDT should only be used for lesions with a depth of $2 \mathrm{~mm}$ or less due to poor clearance rates with thicker tumors [51-54]. The first study showed that AFP was an effective strategy to improve the penetration of the photosensitizing agent prior to PDT [28]. The second study showed that BCCs with a depth of 2-3 $\mathrm{mm}$ and $>3 \mathrm{~mm}$ could result in clearance rates of $94.7 \%$ and $100 \%$, respectively, with different adjunctive laser treatments pre-PDT [31].

Four studies used HFUS to monitor response to treatment and recurrences $[23,30,35,42]$. These studies included BCCs largely treated non-surgically [23, 35, 42]. Only one study included surgically managed BCCs [30]. Two of these four studies did not find HFUS to be helpful for monitoring $[23,35]$. However, it was noted that HFUS was particularly helpful in lesions managed non-surgically to characterize residual disease and recurrences over time [30]. Positive margins significantly increase the risk of recurrence of BCCs, but the literature reports that this risk may vary between 26 and $38.5 \%$ (compared to 5.9$14 \%$ if margins are negative) [55-57]. Along with risk factors discussed in these studies [55-57], HFUS could have a role in identifying which lesions would be more prone to recur, as Raszewska-Famielec's group followed 2 BCCs with positive margins post-excision with interval US screening [30]. The absence of disease on sonographic as-

Performance of HFUS for the Assessment of BCCs sessment informed the decision to monitor rather than re-intervene, and no recurrence was noted during followup [30].

\section{Devices, Spatial Resolution, and Operator Training}

A variety of machines from 10 different companies were used (1 study did not report equipment details) with different processors, probes, and examination parameters. Axial and lateral spatial resolutions reported in 10 of the 30 studies varied widely, respectively, between 50 and $100 \mu \mathrm{m}$ and between 21 and $500 \mu \mathrm{m}$, which likely had a significant impact on the quality of the images obtained and the conclusions that could be drawn from these assessments. We also noted a high variability in operator training throughout the different studies. Eighteen of the 30 studies did not comment on operator experience, making it more difficult to interpret these results.

\section{Discussion}

Our review proved that HFUS can be used as a primary imaging modality to study BCCs. HFUS provides accurate depth measurements, especially for thicker BCCs $(>1 \mathrm{~mm})$. When assessing thickness in more superficial lesions, one should consider higher frequencies such as $\geq 70 \mathrm{MHz}$, although we recognize this is not wide- 
Table 9. Recommended uses for high-frequency ultrasound (HFUS) in the assessment of BCCs

\begin{tabular}{ll}
\hline Recommendations based on our review & $\begin{array}{l}\text { No. of studies by } \\
\text { level of evidence }\end{array}$ \\
dation & $\begin{array}{l}\text { Grade of } \\
\text { recommen- } \\
\text { dation }\end{array}$
\end{tabular}

\section{Morphological characteristics}

Surface measurements

HFUS did not seem more useful than clinical assessment for the determination of surface measurements; further research is needed, particularly with UHFUS*

Depth

2 level $3 b$ studies

C

$[21,48]$

8 level 4 studies $[19,22,24,29,39$,

$41,46,47]$

4 level $3 b$ studies $[20,21,26,48] \quad$ B

- HFUS provides accurate depth measurements, especially for thicker BCCs (>1 mm) 14 level 4 studies [22, 24, 25, 27-

- When assessing thickness in more superficial lesions, one should consider UHFUS

Lateral margins

- Further research is needed for applicability in vivo considering UHFUS

- May be a role for ex vivo margin assessment

Invasion of adjacent structures

Can rule out BCC invasion of adjacent cartilage

$29,31,32,34,38,41,44,45,47]$

2 level 3 b studies $[21,43]$

7 level 4 studies [19, 22, 33, 34, 39,

$44,46]$

2 level $3 b$ studies $[21,48] \quad$ B

1 level 4 study [47]

Diagnosis - detection and characterization

Detection of primary lesions

It can detect and characterize the primary lesions; however, further research is needed with UHFUS

Individual subtype identification

It may support the identification of the subtypes; however, further research is needed with UHFUS

Low-risk vs. high-risk classification

Can reliably help identify higher recurrence risk BCC subtypes

Subclinical lesions

Can help in identifying subclinical lesions (discrete and contiguous)

2 level 3b studies $[40,48]$

B

1 level 3b study [26]

2 level 4 studies $[22,37]$

C

1 level 3b study [36]

4 level 4 studies $[19,23,24,34]$

2 level 3 b studies $[21,48]$

1 level 4 study [34]

Management

Surgical planning

Pre-surgical scans can provide information on local invasion and inform case selection for Mohs

Non-surgical planning (BT and PDT)

- Can reliably help determine the minimal prescription depth, thus minimizing treatment-associated toxicity

- Can help with case selection

- Can help with adjunct treatment choice pre-PDT

Monitoring

- Can help follow lesions after intervention to assess response to treatment and

1 level 3b study [21]

2 level 4 studies $[22,47]$

4 level 4 studies $[28,31,32,41]$

C

monitor for recurrences (particularly for non-surgically managed BCCs)

- Can inform decision to observe vs. re-intervene

* UHFUS, ultra high-frequency ultrasound (i.e., $\geq 30 \mathrm{MHz}$; however, $\geq 70 \mathrm{MHz}$, would be better suited for most superficial BCCs).

ly available. Lateral margin determination in vivo for BCCs did not show convincing evidence for applicability, but there may be a role for ex vivo margin assessment. There appears to be a diagnostic role for HFUS in identifying higher recurrence risk BCC subtypes, which can help in risk stratification. It was consistently observed that HFUS performed better in assessing depth, margins, and identifying aggressive compared to non-aggressive
BCC subtypes for larger tumors. Performance of HFUS is significant in the management of BCCs. We note that pre-surgical scans can provide information on local invasion and inform case selection for Mohs. HFUS can improve safety when used to plan brachytherapy treatments and help with case selection and adjunct treatment choice pre-PDT. Finally, HFUS can help follow lesions after intervention, particularly non-surgical management, over 
time and possibly inform the decision to observe or reintervene (Table 9).

A tendency towards overestimation of length and width for HFUS was noted compared to both clinical and histopathology measurements. This was the case in both in vivo and ex vivo specimens $[22,29,46]$. On histology, overestimation is usually due to inflammation surrounding the tumor, and it usually represents a smaller difference in diameter than what the safety margin would be in the context for a given BCC excision [21, 22]. It is also thought that tissue shrinkage occurring during the processing of a sample for histopathology could explain these discrepancies [21].

Overall, HFUS accurately assessed the depth of BCCs. Of the studies exclusively comparing US depth to histopathology, 6/7 studies reported a moderate to strong correlation. The single study that found no significant association between HFUS and histopathology depths used punch biopsy only as a gold standard [20], while others used full excision. The selection of the biopsy area involves a clinical suspicion of the thickest part of the lesion, which is subject to error. Thus, biopsy may not have captured the deepest point of the lesion.

Several studies reported that depth was overestimated on US assessment $[25,27,44,45]$, which is the more widely accepted notion. Contrary to this, 5 investigations reported that HFUS underestimated depth $[20,21,29,38$, 47]. It has been shown that the excision of a lesion leads to a loss of skin tension, which could result in a greater measured thickness on histopathology. However, this is usually countered by the shrinkage that can occur with fixation, dehydration, and embedding [58]. Crisan et al. proposed that US depth underestimations could be explained by the vascular nature of BCCs that make them more compliant, thus more subject to being mechanically compressed during the US assessment; however, compression during dermatologic examinations is not usually performed because the technique uses a pad of gel on top of the lesion $[16,38]$. Performing an US evaluation after a biopsy will naturally cause some alterations to the lesion's anatomy, contributing to some inflammatory and scar changes depending on the time between biopsy and scan. It is also possible that the deepest part of the tumor was removed on biopsy. Most of the studies performed biopsies or excisions after US; otherwise, sonographic assessments were performed at 1 month post biopsy [20], or they purposefully excluded lesions that had received any types of treatment (drug or surgical) 1 month prior [34].

HFUS requires training of the operators like any other imaging technique, limiting the implementation of the technique in some institutions [59]. The variety of devices and the level of training of the operators may affect the accuracy of the results; however, in this context, ultrasound still seems worthwhile.

In the last few years, technological developments have added ultra-high frequency ultrasound (UHFUS) to the arsenal of dermatological sonography, consisting of assessments at frequencies ranging from $30 \mathrm{MHz}$ up to 100 $\mathrm{MHz}$ [60]. The axial spatial resolution of such a technique is approximately $30 \mu \mathrm{m}$ at $70 \mathrm{MHz}[61,62]$ and allows for exceptional visualization of superficial structures, therefore $\geq 70 \mathrm{MHz}$ would be better suited in superficial BCCs. In deeper lesions lower frequencies are needed because UHFUS has lower penetration. Nowadays, most new ultrasound technologies (HFUS and UHFUS) use variable frequency probes to manage the detection depth so the operator can move between frequencies and adapt the frequency to the depth of the lesion. UHFUS has opened the door to a variety of applications in different disciplines of medicine, but within the dermatological world, it has been used to explore a myriad of pathologies, including oral mucosa disease [63-65], hair pathology [66], systemic sclerosis [67], adnexal tumors $[68,69]$ as well as melanocytic lesions [70], the latter having been largely excluded from conventional HFUS applications. To the best of our knowledge, three studies have thus far investigated the use of UHFUS in BCCs [29, 71,72 ], of which only Nassiri et al. [29] was included in our review as the other two studies only examined one BCC each.

HFUS evaluations of BCCs are not meant to replace histopathology but can enhance clinical practice by providing valuable management-altering information. The technique is safe (non-radiating) and provides real-time insights into the characteristics of the tumor.

\section{Conclusion}

In conclusion, HFUS is an imaging technique that supports the diagnosis and management of BCCs. It would be recommended to assess the extent, mainly depth, and the aggressiveness of the lesions.

\section{Key Message}

We recommend using ultrasound to evaluate the depth and aggressiveness of basal cell carcinomas. 


\section{Statement of Ethics}

Ethical review and institutional approvals were not required as study is based solely on published literature.

\section{Conflict of Interest Statement}

Dr. Ximena Wortsman: received royalties for books from Springer and a Speaker Bureau from Abbvie. No other authors have conflicts of interest to declare.

\section{Funding Sources}

The authors did not receive any funding for this review.

\section{Author Contributions}

A.L.S., A.S., and D.N. performed the literature search and wrote and reviewed the manuscript; A.J., A.A., and E.O. wrote and reviewed the manuscript; X.W. wrote and reviewed the manuscript and supervised the research activities. The authors confirm they have not published, posted, or submitted any related papers from this study.

\section{Data Availability Statement}

The data that support the findings of this study are available from the corresponding author, upon reasonable request.

\section{References}

1 Rigel DS, Friedman RJ, Kopf AW. Lifetime risk for development of skin cancer in the U.S. population: current estimate is now 1 in 5 . J Am Acad Dermatol. 1996;35(6):1012-3.

2 Sng J, Koh D, Siong WC, Choo TB. Skin cancer trends among Asians living in Singapore from 1968 to 2006. J Am Acad Dermatol. 2009; 61(3):426-32.

3 Rudolph C, Schnoor M, Eisemann N, Katalinic A. Incidence trends of nonmelanoma skin cancer in Germany from 1998 to 2010. J Dtsch Dermatol Ges. 2015;13(8):788-97.

4 de Vries E, Louwman M, Bastiaens M, de Gruijl F, Coebergh JW. Rapid and continuous increases in incidence rates of basal cell carcinoma in the southeast Netherlands since 1973. J Invest Dermatol. 2004;123(4):634-8.

5 Staples MP, Elwood M, Burton RC, Williams JL, Marks R, Giles GG. Non-melanoma skin cancer in Australia: the 2002 national survey and trends since 1985. Med J Aust. 2006; 184(1):6-10.

6 Holme SA, Malinovszky K, Roberts DL. Changing trends in non-melanoma skin cancer in South Wales, 1988-98. Br J Dermatol. 2000;143(6):1224-9.

7 Cameron MC, Lee E, Hibler BP, et al. Basal cell carcinoma: Epidemiology; pathophysiology; clinical and histological subtypes; and disease associations. J Am Acad Dermatol. 2019;80(2):303-17.

8 von Domarus H, Stevens PJ. Metastatic basal cell carcinoma. Report of five cases and review of 170 cases in the literature. J Am Acad Dermatol. 1984;10(6):1043-60.

9 Cameron MC, Lee E, Hibler BP, et al. Basal cell carcinoma: Contemporary approaches to diagnosis, treatment, and prevention. J Am Acad Dermatol. 2019;80(2):321-39.

10 Gutzmer R, Solomon JA. Hedgehog Pathway Inhibition for the Treatment of Basal Cell Carcinoma. Target Oncol. 2019;14(3):25367.
11 Leavitt E, Lask G, Martin S. Sonic Hedgehog Pathway Inhibition in the Treatment of Advanced Basal Cell Carcinoma. Curr Treat Options Oncol. 2019;20(11):84.

12 Gonzalez S, Tannous Z. Real-time, in vivo confocal reflectance microscopy of basal cell carcinoma. J Am Acad Dermatol. 2002;47(6): 869-74.

13 Cheng HM, Guitera P. Systematic review of optical coherence tomography usage in the diagnosis and management of basal cell carcinoma. Br J Dermatol. 2015;173(6):137180.

14 Barcaui Ede O, Carvalho AC, Valiante PM, Barcaui CB. High-frequency ultrasound associated with dermoscopy in pre-operative evaluation of basal cell carcinoma. An Bras Dermatol. 2014;89(5):828-31.

15 Kucinskiene V, Samuleniene D, Gineikiene A, Raisutis R, Kazys R, Valiukeviciene S. Preoperative assessment of skin tumor thickness and structure using $14-\mathrm{MHz}$ ultrasound. Medicina (Kaunas). 2014;50(3):150-5.

16 Wortsman X. Atlas of dermatologic ultrasound: Springer; 2018.

17 Whiting P, Rutjes AW, Reitsma JB, Bossuyt PM, Kleijnen J. The development of QUADAS: a tool for the quality assessment of studies of diagnostic accuracy included in systematic reviews. BMC Med Res Methodol. 2003;3:25.

18 Oxford Centre for Evidence-Based Medicine - levels of evidence (March 2009). https:// www.cebm.ox.ac.uk/resources/levels-of-evidence/oxford-centre-for-evidence-basedmedicine-levels-of-evidence-march-2009 (accessed July 25 2021).

19 Alfageme F, Salgüero I, Nájera L, Suarez ML, Roustan G. Increased Marginal Stiffness Differentiates Infiltrative From Noninfiltrative Cutaneous Basal Cell Carcinomas in the $\mathrm{Fa}$ cial Area: A Prospective Study. J Ultrasound Med. 2019;38(7):1841-5.
20 Ballester-Sanchez R, Pons-Llanas O, Llavador-Ros M, et al. Depth determination of skin cancers treated with superficial brachytherapy: ultrasound vs. histopathology. Journal of Contemporary Brachytherapy. 2014;6(4): 356-61.

21 Bobadilla F, Wortsman X, Muñoz C, Segovia L, Espinoza M, Jemec GB. Pre-surgical high resolution ultrasound of facial basal cell carcinoma: correlation with histology. Cancer Imaging. 2008;8(1):163-72.

22 Desai TD, Desai AD, Horowitz DC, Kartono F, Wahl T. The use of high-frequency ultrasound in the evaluation of superficial and nodular basal cell carcinomas. Dermatol Surg. 2007;33(10):1220-7.

23 Hernandez-Ibanez C, Aguilar-Bernier M, Funez-Liebana R, del Boz J, Blazquez $\mathrm{N}$, de Troya M. The Usefulness of High-Resolution Ultrasound in Detecting Invasive Disease in Recurrent Basal Cell Carcinoma After Nonsurgical Treatment. Actas Dermo-Sifiliograficas. 2014;105(10):935-9.

24 Hernandez-Ibanez C, Blazquez-Sanchez N, Aguilar-Bernier M, Funez-Liebana R, RivasRuiz F, de Troya-Martin M. Usefulness of High-Frequency Ultrasound in the Classification of Histologic Subtypes of Primary Basal Cell Carcinoma. Actas Dermo-Sifiliograficas. 2017;108(1):42-51.

25 Hinz T, Ehler LK, Hornung T, et al. Preoperative Characterization of Basal Cell Carcinoma Comparing Tumour Thickness Measurement by Optical Coherence Tomography, 20-MHzUltrasoundandHistopathology. Acta Dermato-Venereologica. 2012;92(2): 132-7.

26 Khlebnikova AN, Molochkov VA, Selezneva EV, Belova LA, Bezugly A, Molochkov AV. Ultrasonographic features of superficial and nodular basal cell carcinoma. Med Ultrason. 2018;20(4):475-9. 
27 Khlebnikova A, Molochkov V, Selezneva E, et al. Basal cell carcinoma invasion depth determined with 30 and $75 \mathrm{MHz}$ high-frequency ultrasound and histopathology - a comparative study. Medical Ultrasonography. 2020;22(1):33-8.

28 Lippert J, Smucler R, Vlk M. Fractional Carbon Dioxide Laser Improves Nodular Basal Cell Carcinoma Treatment with Photodynamic Therapy with Methyl 5-Aminolevulinate. Dermatol Surg. 2013;39(8):1202-8.

29 Nassiri-Kashani M, Sadr B, Fanian F, et al. Pre-operative assessment of basal cell carcinoma dimensions using high frequency ultrasonography and its correlation with histopathology. Skin Research and Technology. 2013; 19(1):E132-E8

30 Raszewska-Famielec M, Borzêcki A, Krasowska D, Chodorowska G. Clinical usefulness of high-frequency ultrasonography in the monitoring of basal cell carcinoma treatment effects. Postepy Dermatol Alergol. 2020; 37(3):364-70.

31 Smucler R, Kriz M, Lippert J, Vlk M. Ultrasound Guided Ablative-Laser Assisted Photodynamic Therapy of Basal Cell Carcinoma (US-aL-PDT). Photomed Laser Surg. 2012 30(4):200-5.

32 Tormo A, Celada F, Rodriguez S, et al. Non-melanoma skin cancer treated with HDR Valencia applicator: clinical outcomes. Journal of Contemporary Brachytherapy. 2014;6(2):167-72.

33 Vilas-Sueiro A, Alfageme F, Salgüero I, De las Heras C, Roustan G. Ex Vivo High-Frequency Ultrasound for Assessment of Basal Cell Carcinoma. J Ultrasound Med. 2019;38(2):52931.

34 Wang SQ, Liu J, Zhu QL, et al. High-frequency ultrasound features of basal cell carcinoma and its association with histological recurrence risk. Chinese Medical Journal. 2019; 132(17):2021-6.

35 Wenande E, Hendel K, Mogensen M, et al. Efficacy and Safety of Laser-Assisted Combination Chemotherapy: An Explorative ImagingGuided Treatment With 5-Fluorouracil and Cisplatin for Basal Cell Carcinoma. Lasers in Surgery and Medicine. 2020.

36 Wortsman X, Vergara P, Castro A, et al. Ultrasound as predictor of histologic subtypes linked to recurrence in basal cell carcinoma of the skin. J Eur Acad Dermatol Venereol. 2015; 29(4):702-7.

37 Bens G, Binois R, Roussel A, Kerdraon R, Esteve E. High-resolution ultrasonogrophy for differential diagnosis between nodular basal carcinoma and sebaceous hyperplasia of the face: A pilot study. Annales De Dermatologie Et De Venereologie. 2015;142(11):646-52.

38 Crisan M, Crisan D, Sannino G, Lupsor M, Badea R, Amzica F. Ultrasonographic staging of cutaneous malignant tumors: an ultrasonographic depth index. Arch Dermatol Res. 2013;305(4):305-13.

39 Marmur ES, Berkowitz EZ, Fuchs BS, Singer GK, Yoo JY. Use of High-Frequency, HighResolution Ultrasound Before Mohs Surgery. Dermatol Surg. 2010;36(6):841-7.
40 Uhara H, Hayashi K, Koga H, Saida T. Multiple hypersonographic spots in basal cell carcinoma. Dermatol Surg. 2007;33(10):1215-9.

41 Goyal U, Pan J, Cui H, Stea B. Does ultrasound measurement improve the accuracy of electronic brachytherapy in the treatment of superficial non-melanomatous skin cancer? J Contemp Brachytherapy. 2017;9(1):14-9.

42 Goyal U, Suszko J, Stea B. The feasibility of using ultrasound during follow-up for superficial non-melanoma skin cancers after electronic brachytherapy. J Contemp Brachytherapy. 2017;9(6):535-9.

43 Jambusaria-Pahlajani A, Schmults CD, Miller CJ, et al. Test Characteristics of High-Resolution Ultrasound in the Preoperative Assessment of Margins of Basal Cell and Squamous Cell Carcinoma in Patients Undergoing Mohs Micrographic Surgery. Dermatologic Surgery. 2009;35(1):9-16.

44 Jovanovic DL, Katic V, Jovanovic B. Value of preoperative determination of skin tumor thickness with $20-\mathrm{MHz}$ ultrasound. Arch Dermatol. 2005;141(2):269-70.

45 Mogensen M, Nürnberg BM, Forman JL, Thomsen JB, Thrane L, Jemec GB. In vivo thickness measurement of basal cell carcinoma and actinic keratosis with optical coherence tomography and 20-MHz ultrasound. $\mathrm{Br}$ J Dermatol. 2009;160(5):1026-33.

46 Pasquali P, Freites-Martinez A, Fortuño-Mar A. Ex vivo high-frequency ultrasound: A novel proposal for management of surgical margins in patients with non-melanoma skin cancer. J Am Acad Dermatol. 2016;74(6):127880.

47 Song WJ, Choi HJ, Lee YM, et al. Clinical analysis of an ultrasound system in the evaluation of skin cancers: correlation with histology. Ann Plast Surg. 2014;73(4):427-33.

48 Wortsman X, Wortsman J. Clinical usefulness of variable-frequency ultrasound in localized lesions of the skin. J Am Acad Dermatol. 2010;62(2):247-56.

49 Quazi SJ, Aslam N, Saleem H, Rahman J, Khan S. Surgical Margin of Excision in Basal Cell Carcinoma: A Systematic Review of Literature. Cureus. 2020;12(7):e9211.

50 Paravati AJ, Hawkins PG, Martin AN, et al. Clinical and cosmetic outcomes in patients treated with high-dose-rate electronic brachytherapy for nonmelanoma skin cancer. Pract Radiat Oncol. 2015;5(6):e659-64.

51 Collier NJ, Haylett AK, Wong TH, et al. Conventional and combination topical photodynamic therapy for basal cell carcinoma: systematic review and meta-analysis. Br J Dermatol. 2018;179(6):1277-96.

52 Collier NJ, Rhodes LE. Photodynamic Therapy for Basal Cell Carcinoma: The Clinical Context for Future Research Priorities. Molecules. 2020;25(22).

53 Morton CA, Szeimies RM, Basset-Seguin N, et al. European Dermatology Forum guidelines on topical photodynamic therapy 2019 Part 1: treatment delivery and established indications - actinic keratoses, Bowen's disease and basal cell carcinomas. J Eur Acad Dermatol Venereol. 2019;33(12):2225-38.

54 Wong TH, Morton CA, Collier N, et al. British Association of Dermatologists and British Photodermatology Group guidelines for topical photodynamic therapy 2018. Br J Dermatol. 2019;180(4):730-9.

55 Nagore E, Grau C, Molinero J, Fortea JM. Positive margins in basal cell carcinoma: relationship to clinical features and recurrence risk. A retrospective study of 248 patients. J Eur Acad Dermatol Venereol. 2003;17(2):167-70.

56 Sartore L, Lancerotto L, Salmaso M, et al. Facial basal cell carcinoma: analysis of recurrence and follow-up strategies. Oncol Rep. 2011;26(6):1423-9.

57 Codazzi D, Van Der Velden J, Carminati M, et al. Positive compared with negative margins in a single-centre retrospective study on 3957 consecutive excisions of basal cell carcinomas. Associated risk factors and preferred surgical management. J Plast Surg Hand Surg. 2014;48(1):38-43.

58 Salmhofer W, Rieger E, Soyer HP, Smolle J, Kerl H. Influence of skin tension and formalin fixation on sonographic measurement of tumor thickness. J Am Acad Dermatol. 1996; 34(1):34-9.

59 Wortsman X, Alfageme F, Roustan G, et al Guidelines for Performing Dermatologic Ultrasound Examinations by the DERMUS Group. J Ultrasound Med. 2016;35(3):577-80.

60 Izzetti R, Vitali S, Aringhieri G, et al. UltraHigh Frequency Ultrasound, A Promising Diagnostic Technique: Review of the Literature and Single-Center Experience. Can Assoc Radiol J. 2020:846537120940684.

61 Greco A, Albanese S, Auletta L, et al. HighFrequency Ultrasound-Guided Injection for the Generation of a Novel Orthotopic Mouse Model of Human Thyroid Carcinoma. Thyroid. 2016;26(4):552-8.

62 Schuetzenberger K, Pfister M, Messner A, et al. Comparison of optical coherence tomography and high frequency ultrasound imaging in mice for the assessment of skin morphology and intradermal volumes. Sci Rep. 2019; 9(1):13643

63 Izzetti R, Vitali S, Aringhieri G, et al. The efficacy of Ultra-High Frequency Ultrasonography in the diagnosis of intraoral lesions. Oral Surg Oral Med Oral Pathol Oral Radiol. 2020;129(4):401-10.

64 Izzetti R, Vitali S, Aringhieri G, et al. Discovering a new anatomy: exploration of oral mucosa with ultra-high frequency ultrasound. Dentomaxillofac Radiol. 2020;49(7): 20190318.

65 Izzetti R, Vitali S, Oranges T, et al. Intraoral Ultra-High Frequency Ultrasound study of oral lichen planus: A pictorial review. Skin Res Technol. 2020;26(2):200-4.

66 Kinoshita-Ise M, Ohyama M, Ramjist JM, et al. Ultra high-frequency ultrasound with seventy-MHz transducer in hair disorders: Development of a novel noninvasive diagnostic methodology. J Dermatol Sci. 2021. 
67 Naredo E, Pascau J, Damjanov N, et al. Performance of ultra-high-frequency ultrasound in the evaluation of skin involvement in systemic sclerosis: a preliminary report. Rheumatology (Oxford). 2020;59(7):1671-8.

68 Shinaoka A, Nakahara R, Saeki M. The use of $33 \mathrm{MHz}$ ultra-high-frequency ultrasonography for the evaluation of sweat glands in the axilla with osmidrosis. PLoS One. 2021;16(5): e0251600.
69 Li L, Xu J, Wang S, Yang J. Ultra-High-Frequency Ultrasound in the Evaluation of Paediatric Pilomatricoma Based on the Histopathologic Classification. Front Med (Lausanne). 2021;8:673861.

70 Faita F, Oranges T, Di Lascio N, et al. Ultrahigh-frequency ultrasound and machine learning approaches for the differential diagnosis of melanocytic lesions. Exp Dermatol. 2021.
71 Hayashi K, Okuyama R, Uhara H. Waterbased correction fluid is a useful skin marker for determination of the tumor margin of basal cell carcinoma under high-frequency ultrasound. J Dermatol. 2016;43(7):823-5.

72 Rohrbach DJ, Muffoletto D, Huihui J, et al. Preoperative mapping of nonmelanoma skin cancer using spatial frequency domain and ultrasound imaging. Acad Radiol. 2014;21(2): 263-70. 